4. Социальная педагогика: Курс лекций: Учебное пособие для студентов высших учебных заведений / Под общей редакцией. М.А. Галагузовой. - М.: ВЛАДОС, 2001. $380 \mathrm{c}$

\title{
Анализ основных направлений энергосбережения предприятия ООО «Сибирь Техник»
}

Киселёва Е.В., студент, Новосибирский государственный технический университет, 2. Новосибирск E-mail: kiskat22@mail.ru

Научный руководитель: к.т.н., доцент Путилова Н.Н.

Техническая служба с цехом оперативного обслуживания была образована в аэропорту «Толмачево» в 1957г. С 2016 г. «Сибирь Техник» отделилось от аэропорта, и образовало отдельное Общество с ограниченной ответственностью «Сибирь Техник».

- Основными направлениями деятельности Общества являются:

- Оперативное и периодическое техническое обслуживание ВС зарубежного производства;

производства;

- Инженерное сопровождение и планирование ТО ВС зарубежного

- Обслуживание и ремонт компонентов ВС зарубежного производства;

- Неразрушающий контроль конструкций и компонентов ВС зарубежного производства;

Была проведена характеристика персонала. Которая показала, что общая численность составляет 501 человек, из них работников с высшим образованием составляет больше половины общей численности, а конкретно 250 человек. Большей частью персонала являются мужчины, а средний возраст работников составляет около 40 лет.

С июня 2016 года «Сибирь Техник» отделился от Аэропорта Толмачево. На настоящий момент основными задачами, являющимися актуальными для Общества в связи с его отделением являются:

Развитие и становление службы энергоснабжения.

Пересмотр систем коммерческого учета.

Создание энергопаспорта.

Унификация договорных отношений по энергоснабжению.

Планирование и реализация мероприятий по энергоэффективности.

Проводя анализ особенностей энергоснабжения ООО «Сибирь Техник» в связи с изменением его статуса, следует отметить, что до июня 2016 общество было зависимо от аэропорта Толмачево, а с 2016 года отделилось и стало существовать как отдельное общество.

Так как Общество «Сибирь Техник» раньше было дочерним филиалом Аэропорта «Толмачево», то договор на электрообеспечение был заключен с аэропортом, а тот в свою очередь являлся перепродавцом электроэнергии. В связи с 
отделением произошло изменение и во взаимоотношениях, и в настоящее время деятельность по обеспечению Э/Э обеспечивается на основе договора № O-167 с энергосбытовой компанией, где гарантированным поставщиком является НовосибирскЭнергосбыт.

Схема обеспечения тепловой энергией в целом осталась прежней и прописана договором № 79-160487 в котором говорится о том, что поставщиком тепло энергией является электроснабжающая организация- аэропорт «Толмачево», на территории которого имеется собственная котельная. В договорных отношениях прописан максимум тепловой нагрузки-7,184 Гкал/час, в том числе на горячее водоснабжение0,086 Гкал/час, на отопление- 5,733 Гкал/час.

\title{
Список литературы:
}

1. Веретенникова И.И. Факторы и условия экономического роста: Монография/ И.И. Веретенникова. - СПб.: Химиздат, 2012. - 136 с.

2. Гранберг Д. Статистическое моделирование и прогнозирование/ Д. Гранберг. М.: Финансы и статистика, 2012. - 352 с.

3. Иванов Л.Б. Основы менеджмента: понятие кибернетики и общие вопросы управления: Учеб.пособие / Л.Б. Иванов, Н.В. Мурашкин, О.Н. Тюкина, Е.В. Моштакова, В.А. Яллай, Н.М. Сеник. - Псков: ПГПИ им. С.М. Кирова, 2014. - 96 с.

4. Чейз Р.Б., Джейкобз Ф.Р., Аквиланов Н.Дж. Производственный и операционный менеджмент/ Р.Б. Чейз, Ф.Р. Джейкобз, Н.Дж. Аквиланов. - М.: Изд-во «Вильямс», 2013. - 950с.

\section{Мониторинг использования земельного фонда (Чернушинский район, Пермский край)}

\author{
Кислицина Е.Ю., студент, \\ Уральский государственный аграрный университет, \\ 2. Екатеринбург \\ E-mail: lena-voronova15@yandex.ru
}

Научный руководитель: к.2.-м.н. Старицына И.А.

Чернушинский район находится в Пермском крае. В настоящее время на территории района находится 15 поселений, количество населенных пунктов составляет 80, численность населения 50,8 тысяч человек. Очень часто в городских поселениях возникает необходимость перевода земельных участков из одной категории в другую. Расширяющиеся города постепенно поглощают свои окрестности. По этой причине вынужденно сокращаются земли запаса, лесного фонда и сельскохозяйственного назначения. Чернушинский район в настоящее время активно развивается, поэтому под новое строительство требуются земельные участки. Свободных земель в районе недостаточно, поэтому приходится переводить земельные участки из одной категории в другую. Основные востребованные в настоящее время категории - это земли промышленности и земли населённых пунктов. С коммерческой точки зрения стоит отметить, что земельные участки данных двух категорий имеют 